\title{
THE VILLAGE DEVELOPMENT IN VILLAGE AUTONOMY CONTEXT BASED ON COMMUNITY EMPOWERMENT (The implementation of Act Number 6 of 2014 concerning Villages)
}

\author{
Sri Pujiningsih \\ Fakultas Hukum Universitas Pekalongan \\ JL. Sriwijaya No.3 Pekalongan \\ E-mail : spningsih.unikal@gmail.com
}

\begin{abstract}
The village development carried out in the village cannot be separated from the village autonomy authority that it has. The purpose of village development is directed at improving the welfare of the village community, supported by more and more village affairs now as stipulated in Act Number 6 of 2014. Village development cannot be carried out by one party alone, without involving other parties, therefore it must be coordinated with other parties both with the government and the community. In community empowerment it means that there is a process that builds the community through developing community capacity, changing human behavior and even reaching the level of community organizers. Village development in the context of village autonomy based on community empowerment does not always lead to the form of programs that are physical in nature. Through this writing, village development is more directed at the form of community empowerment programs.
\end{abstract}

Keywords : village development, village autonomy, community empowerment

\begin{abstract}
Abstrak : Pembangunan desa yang dilaksanakan di desa tidak terlepas dari kewenangan otonomi desa yang dimilikinya. Tujuan pembangunan desa diarahkan untuk peningkatan kesejahteraan masyarakat desanya, didukung pula urusan desa sekarang ini semakin banyak sebagaimana diatur dalam UU Nomor.6 Tahun 2014. Pembangunan desa tidak mungkin bisa dilaksanakan oleh satu pihak saja, tanpa melibatkan pihak lainnya, oleh karena itu harus melalui koordinasi dengan pihak lain baik dengan pemerintah maupun masyarakat. Dalam pemberdayaan masyarakat berarti ada suatu proses yang membangun masyarakat melalui pengembangan kemampuan masyarakat, perubahan perilaku manusia dan bahkan bisa sampai pada tingkatan pengorganisasi masyarakat. Pembangunan desa dalam konteks otonomi desa yang berbasis pada pemberdayaan masyarakat ini tidak selalu mengarah pada bentuk program pembangunan yang sifatnya fisik. Melalui tulisan ini pembangunan desa lebih diarahkan pada bentuk program-program pemberdayaan masyarakat.
\end{abstract}

Kata Kunci : pembangunan desa, otonomi desa, pemberdayaan masyarakat

\section{Preliminary}

The village was formed long before the Republic of Indonesia (NKRI) was born. Its existence is a forerunner to an autonomous democratic system, has full sovereignty and has its own governance mechanisms and social norms.

The village is the embrio to the formation of political and governmental society long before the Indonesian state was formed. The village is a small community unit like a large household, led by the most elder or respected family member based on lineage. The pattern of relationships and the level of communication is still very low, especially in remote and remote rural areas. ${ }^{1}$

The village has original and traditional rights in regulating and managing the interests of

\footnotetext{
${ }^{1}$ Adon Nasrullah Jamaludin,2015, Sosiologi

Perdesaan, Pustaka Setia,Bandung,hlm,1
} 
the local community and contributing to the realization of the ideals of independence based on the 1945 Republic of Indonesia State Constitution.

The village has developed in various forms so that it needs to be protected and empowered to be strong, advanced, independent, and democratic so that it can create a strong foundation in carrying out governance and development towards a just, prosperous, and prosperous society.

The village has original autonomy rights based on customary law, can determine the composition of the government, manage and manage the household, and have wealth and assets. therefore, the existence of the village needs to be emphasized to realize the welfare of the village community. However, the deregulation and restructuring of villages after several amendments to the state constitution and its laws and regulations gave rise to a new perspective on village governance in Indonesia. With the enactment of Law No. 6 of 2014 concerning Villages, as an autonomous region, is indeed granted special privileges, including those related to financial management and allocation of village funds, election of village heads and the process of village development. ${ }^{2}$

According to Juliantara, village autonomy is not a sovereignty but an acknowledgment of the right to regulate its own household affairs on the basis of community initiatives, Autonomy by itself can close the door of institutional intervention on it. On the other hand, the intervention process which is forced, abrupt, and does not see the reality of the community is not justified. ${ }^{3}$

The Village development as reviewed in Law No. 6 of 2014 concerning Villages illustrates that village affairs are increasing. Moreover, it is also supported by generous financial assistance from the central government. The problem is that many villages use the funds to be allocated more to physical development, while the allocation to non-physical development is still groping because not all villages understand this.

The philosophy of village autonomy is seen as an authority that already exists, growing rooted in village customs does not also mean

\footnotetext{
2https://lbhsembilandelapan.wordpress.com/2015 /08/10/otonomi-menurut-undang-undang-no-6tahun-2014-tentang-desa/

3 Juliantara Dadang, 2003, Pembaharuan Desa, Bertumpu pada Angka Terbawah, Yogyakarta, Lappera Pustaka Utama; Hlm. 116
}

giving or decentralization. Village autonomy also means the ability of communities to regulate their own household affairs and is formally legally regulated by the central government through law. ${ }^{4}$

\section{Problems}

The study in this paper is to highlight village development oriented to the context of community empowerment. The issues to be examined are: How is village development in the context of village autonomy based on community empowerment and what are the aims and forms of community empowerment? So that the community does not always have an understanding that village development is always in physical form, but non-physical development in the form of empowerment programs is also very necessary and no less important.

\section{The Village Development in the Context of Community Autonomy Based on Community Empowerment}

\section{Theory Study on Village Autonomy} Said that Widjaja, village autonomy was genuine, rounded and whole, and not a gift from the government. Instead the government is obliged to respect the original autonomy held by the village. As a legal community unit that has an original arrangement based on privileges, villages can carry out legal actions both public and civil law, possess wealth, property and can be prosecuted and sue before the court. ${ }^{5}$

\section{The Village Development}

As regulated in Law No. 6 of 2014, Article 1 Number 1 referred to as Village is a village and a customary village or referred to by another name, hereinafter referred to as Village, is a legal community unit that has an area boundary authorized to regulate and manage

\footnotetext{
${ }^{4}$ Sumber Sapari. Tata Pemerintahan dan administrasi Pemerintahan Desa, Jakarta : Ghalia Indonesia, Hlm. 41

5 Widjaja, HAW. 2003. Otonomi Desa. Jakarta: PT Raja Grafindo Persada, Hlm. 165
} 
government affairs, the interests of the local community based on community initiatives, original rights, and / or traditional rights recognized and respected in the system of government of the Unitary Republic of Indonesia.

Based on the background of the constitutional journey of the Republic of Indonesia, the village has developed in various forms so that it needs to be protected and empowered to be strong, advanced, independent, and democratic so that it can create a strong foundation in carrying out governance and development towards a just, prosperous, and prosperous society.

Said that Suryono, the purpose of development has two stages. First, development is essentially aimed at eradicating poverty. If this goal has begun to feel the results, then the second stage is to create opportunities for citizens to be able to live happily and meet all their needs. 6

In order for development to succeed, many things need to be considered, one of which is community involvement in development. According to Sanit, development began with community involvement. There are several advantages when a community is involved in development planning. First, development will proceed according to community needs. This means that, if the community is involved in development planning, there will be control over the development. Second, community-oriented development will create political stability. Because the community participates in development planning, so the community can be in control of the ongoing development. Development can be interpreted as a conscious effort in a series of activities to achieve a change from a bad state to a better condition carried out by a certain community in a country. ${ }^{7}$

The level of participation in development is needed widely from planning to evaluation later. The government has a dominant role from the start of planning to the implementation of development programs. And the administration of village government is arranged in the village development planning which is a unity in the district / city regional development planning system.

\footnotetext{
${ }^{6}$ Suryono, Agus. 2001. Teori dan Isu Pembangunan. Malang: Universitas Malang Press, hlm.31

7 Ibid., hlm.32
}

In realizing village development in accordance with what is expected, it is necessary to pay attention to several approaches with specific characteristics which are at the same time the identity of village development itself, as stated by C.S.T., namely multi-sectoral comprehensive covering various aspects, both welfare and security aspects with an integrated implementation mechanism and system between various government and community activities. The integration of sectoral and regional targets with the essential needs of community activities. Equitable distribution and distribution of overall rural development including villages in the area. An integrated pattern with national and regional development and rural areas and urban areas and between medium and small area development areas. Mobilize community participation and self-help and also dynamite elements of personality with timely technology. So in realizing village development it must cover various aspects, not from just one aspect, so that village development can be in accordance with what is desired. The development of the village must cover various aspects of life and livelihood, meaning that it must involve all. 8

The autonomy inherent in villages differs from the autonomy held by provincial and district / city regions. Autonomy owned by the village based on its origin and customs, not based on the surrender of authority from the government. Village autonomy is the right, authority and obligation to regulate and manage their own government affairs and community interests based on the origin and socio-cultural values that exist in the community to grow and develop following the development of the village.

The Act Number. 6 of 2014 concerning Villages Article 18 explains that Village Authorities include authority in the area of administering Village Government, implementation of Village Development, fostering Village community, and empowerment of Village communities based on community initiatives, rights of origin, and village customs. Next Article 19 outlines the Village Authority includes:

1. authority based on original rights;

2. Village-scale local authority;

3. authority assigned by the Government, Provincial Regional Government, or

${ }^{8}$ C.S.T Kansil, 1983, Desa Kita Dalam Peraturan Tata Pembangunan Desa. Jakarta: Ghalia Nasional. Hlm. 251. 
Regency / City Regional Government; and other authorities assigned by the Government, Provincial Government, or Regency / City Government in accordance with statutory provisions.

\section{The Village Community Empowerment, Purpose and Shape}

The concept of empowerment includes the notion of community development and communitybased development. Related to this understanding, the need to first understand the meaning and meaning of empowerment and community empowerment. People who have achieved collective goals are empowered through their independence, even it is a "necessity" to be more empowered through their own efforts and accumulation of knowledge, skills and other sources in order to achieve their goals without relying on the help of external relations. ${ }^{9}$

Payne (1997) explains that empowerment is essentially aimed at helping clients gain power, strength and ability to make decisions and actions to be taken and related to the client's self, including reducing personal and social constraints in taking action ... People who have achieving collective goals is empowered through its independence, even it is a "must" to be more empowered through their own efforts and the accumulation of knowledge, skills and other resources in order to achieve goals without depending on the help of external relations. The implementation of the village government empowerment policy is very urgent to continue. Assuming that if the village government is empowered, then they have the ability to fulfill their own needs independently. Then they can form an independent village government, independent of outsiders. One form of operational efforts to establish village government is development. The general understanding of development is the change in physical form towards progress. Village development is identified with the physical construction of existing infrastructure and facilities in the village. Furthermore, infrastructure and facilities will be utilized by rural communities to support their lives. While village empowerment is

https://www.academia.edu/9164519/Pemberdaya an_Masyarakat_Dalam_Pembangunan_Ekonomi_ Desa another form of village development that is not physical in nature. ${ }^{10}$

According to Mardikanto there are six objectives of community empowerment, namely: 11

1. Institutional improvement (better institution). By improving the activities / actions taken, it is expected to improve institutions, including the development of a business partnership network.

2. Better business. Improvement of education (enthusiasm for learning), improvement of business accessibility, activities and institutional improvement, are expected to improve the business conducted.

3. Better income. With the improvement of the business carried out, it is expected to be able to improve the income it receives, including the income of the family and community.

4. Improvement of the environment (better environment). Revenue improvement is expected to improve the environment (physical and social), because environmental damage is often caused by poverty or limited income.

5. Better living. An improved income level and environmental conditions are expected to improve the living conditions of each family and community.

6. Better community. A better life, supported by a better (physical and social) environment, is expected to lead to a better community life.)

The community empowerment is one of the village government programs in utilizing all available resources in order to develop and can help the process of village progress. The targets in this community empowerment program cover all fields, ranging from government, institutions,

\footnotetext{
10Azam Awang, 2010, Implementasi Pemberdayaan

Pemerintah Desa, Pustaka Pelajar, Yogyakarta. Hlm, 22

11 Mardikanto, 2014, CSR (Corporate Social

Responsibility)(Tanggungjawab Sosial Korporasi).

Bandung: Alfabeta Hlm. 202
} 
health, community economics, technology, and education. The scope of the programs include:

1. Community Empowerment in the field of Village Governance

Community empowerment in the field of village governance includes all HR in the village administration, such as the village head, village officials and $\mathrm{BPD}$. This form of empowerment can take the form of training, deliberations in the preparation of village programs, coordination in the implementation of village programs, and improving the quality of performance in village governance. This empowerment program is provided for the purpose of increasing the performance of village governments in developing and advancing villages.

2. The Community empowerment in the institutional field 12

The community empowerment program in the institutional field covers all community institutions in the village. This program aims to build a more targeted, productive and organized institution. The form of this empowerment program can be in the form of training, organizing activities, and improving facilities / infrastructure. The existence of an empowerment program in the institutional sector is expected to improve the performance of institutions so that they can assist the village government in carrying out the development wheel).

4. The Community empowerment in the economic field

This community empowerment program in the economic field is very important and is a government program to improve the village economy, so that the community becomes prosperous and independent. This program can include, among others: empowerment of UKM, home industries, BUMDesa (the existence of these institutions is predicted as a strength to be able to encourage improvement in welfare by means of village economic productivity

12

http://www.aminjaya.desa.id/page/detail/progra m-pemberdayaan-masyarakat-desa by adjusting the variety of potentials owned by each village), farmer groups (in the form of training and fostering farmers), markets (for example from the agricultural produce of their village communities will be sold through markets), and economic support other society. The form of this empowerment program can be in the form of training, workshops, financiers, production equipment assistance, improvement of facilities / infrastructure and others.

4. The Community empowerment in the health sector

The community empowerment program in the health sector aims to improve the quality of life and care for their health. The form of this empowerment program can be in the form of improving health facilities and infrastructure (renovating inadequate Puskesmas buildings), increasing professional and adequate medical personnel, promoting and counseling health programs that aim to increase public awareness for healthy behavior (for example: there are still many villagers who awareness is still minimal with the use of private latrines, this program must be provided in an intense and sustainable manner, supported by financial assistance to build a proper toilet.)

5. The Community Empowerment in the field of education.

The community empowerment program that is no less important is the field of education. Education is a village government program in improving community education so as to know various things around it, considering that the village has not implemented education optimally because many villages have not been properly educated. The form of empowerment for example includes the improvement of facilities and infrastructure in the form of school building construction. not yet available or renovating buildings that are no longer suitable for use for facilities for school students who need attention. Besides fulfilling the teaching staff in schools that have not been adequate, through teacher training, 
providing tuition assistance for underprivileged communities in order to receive education as they should, provide scholarships for outstanding students, and so on ..

6. Empowerment through Appropriate Technology Development and Utilization Program ${ }^{13}$

Program for the Development and Utilization of Appropriate Technology is the availability of Appropriate Technology (TTG) units especially in supporting programs to improve community technology and support regional strategic programs, such as the availability of corn, cocoa, coffee and cattle. The strategic values of this program are:

- Increase the effectiveness and efficiency of local products (community technology)

- Increased product sales value of micro and small businesses in utilizing regional potentials

- Supports food production and diversification improvement programs ).

As stipulated in Law Number. 6 of 2014, that the development and empowerment of rural communities is carried out with assistance. This assistance effort is one of the important steps taken to accelerate the achievement of independence and prosperity of the community. Independence and welfare of the community can be achieved, among others, through increased knowledge, attitudes, skills, behavior, abilities, awareness and utilizing resources in accordance with the essence of the problems and priorities of the needs of rural communities.

Community facilitation in this context is not merely a matter of completing development project targets, but in implementing the Village Law so that it can be realized systematically, consistently and sustainably, there will be more demands in the future, namely assistance that can produce cadres capable of giving birth to strength the people of the village as a fortress of the Republic of Indonesia. Village community assistants must be placed as part of efforts to uphold national and state sovereignty, cadres who are able to move the dynamics of life in a village that is sovereign in the political field, independent in the economic field and has a personality in the cultural field.

The core business of village community empowerment is the strengthening of the people as a social learning process that is learning by capacity and learning by doing that are integrated in all development practices at the community level. Community empowerment is a variant of the process of reforming the politicaleconomic order through a process of social transformation.

Politically, the empowerment of rural communities here is interpreted as a form of expression of the participation of the community's ability to express their interests in a democratic manner in the public sphere.

\section{Closing}

The Village development in the context of village autonomy based on community empowerment aims to increase the independence and prosperity of the village community. One of the things about the success of development is the involvement of the community in development.

The development and empowerment of rural communities is pursued through mentoring efforts. Assistance efforts are made to accelerate the achievement of independence and prosperity of the community.

13 https://bpmpdesa.wordpress.com/programkegiatan/ 


\section{REFERENCES}

\section{Books}

Adon Nasrullah Jamaludin, 2015, osiologi Perdesaan, Pustaka Setia, Bandung,

Azam Awang, 2010, Implementasi

Pemberdayaan Pemerintah Desa, Pustaka Pelajar, Yogyakarta

C.S.T Kansil, 1983, Desa Kita Dalam Peraturan Tata Pembangunan Desa. Jakarta: Ghalia

Juliantara Dadang, 2003, Pembaharuan Desa,Bertumpu pada Angka Terbawah, Yogyakarta, Lappera Pustaka Utama

Mardikanto, 2014, CSR (Corporate Social

Responsibility)(Tanggungjawab Sosial Korporasi). Bandung: Alfabeta

Sumber Sapari. Tata Pemerintahan dan administrasi Pemerintahan Desa, Jakarta : Ghalia Indonesia,
Suryono, Agus. 2001. Teori dan Isu Pembangunan. Malang: Universitas Malang Press

Widjaja, HAW. 2003. Otonomi Desa. Jakarta: PT Raja Grafindo Persada

Internet

\section{Error! Hyperlink reference not valid.}

https://www.academia.edu/9164519/Pemberda yaan_Masyarakat_Dalam_Pembangunan_ Ekonomi_Desa

http://www.aminjaya.desa.id/page/detail/progr am-pemberdayaan-masyarakat-desa

https://bpmpdesa.wordpress.com/programkegiatan/

https://asepjazuli.blogspot.com/2017/12/uudesa-dan-pemberdayaan-masyarakatdesa.html 